\title{
Nietzsche, Dewey, and the Artistic Creation of Truth
}

Jim Garrison

\section{OpenEdition}

\section{Journals}

Electronic version

URL: http://journals.openedition.org/ejpap/386

DOI: $10.4000 /$ ejpap.386

ISSN: 2036-4091

\section{Publisher}

Associazione Pragma

\section{Electronic reference}

Jim Garrison, « Nietzsche, Dewey, and the Artistic Creation of Truth », European Journal of Pragmatism and American Philosophy [Online], VII-1 | 2015, Online since 07 July 2015, connection on 19 April 2019 URL : http://journals.openedition.org/ejpap/386 ; DOI : 10.4000/ejpap.386

This text was automatically generated on 19 April 2019

\section{(c) $\Theta \Theta \Theta$}

Author retains copyright and grants the European Journal of Pragmatism and American Philosophy right of first publication with the work simultaneously licensed under a Creative Commons AttributionNonCommercial-NoDerivatives 4.0 International License. 


\title{
Nietzsche, Dewey, and the Artistic Creation of Truth
}

\author{
Jim Garrison
}

\section{AUTHOR'S NOTE}

The author wishes to acknowledge helpful comments by the anonymous reviewers.

Whatever has value in our world now does not have value in itself, according to its nature Nature is always value-less, but has been given value at some time as a present - and it was we who gave and bestowed it. Only we have created the world that concerns man! (Nietzsche, 1882/1974:

$\S 301)^{1}$

An empirical method which remains true to nature does not "save"; it is not an insurance device nor a mechanical antiseptic. But it inspires the mind with courage and vitality to create new ideals and values in the face of the perplexities of a new world. (LW 1: 4)

\section{Introduction}

1 Let us focus on the following famous passage from Friedrich Nietzsche's (1873/1999) "On Truth and Lying in a Non-Moral Sense": "What, then, is truth? A mobile army of metaphors, metonyms, and anthropomorphisms" (\$1). We will see that John Dewey entirely agrees with this statement. Lakoff and Johnson (1999) and Johnson (2007) make extensive use of Dewey in presenting their theory of metaphor. In so doing, they mobilize an army of metaphors, metonyms, and, by grounding their theory on embodied action, 
embrace perspectival anthropomorphism. While strongly endorsing this approach, I take a different route.

Nietzsche has a rich and novel understanding of metaphor and metonymy that he uses to comprehend the creation of the identity of things, free will, causation, and necessity as serving anthropomorphic purposes. So does Dewey. The result of our inquiry is a surprisingly poetic and rhetorical interpretation of Dewey that should not astonish anyone who reads him carefully. ${ }^{2}$ We arrive at this radical reading of Deweyan pragmatism by a metaphorical transfer from Nietzsche as the more familiar source domain to Dewey as the target domain. ${ }^{3}$

We will call attention to the primordial role of artistic creation in Dewey's philosophy of reconstruction. In his essay, "Construction and Criticism," Dewey writes:

I have used the word construction rather than creation because it seems less pretentious. But what I mean by it is the creative mind, the mind that is genuinely productive in its operations. We are given to associating creative mind with persons regarded as rare and unique, like geniuses. But every individual is in his own way unique. (LW 5: 127)

4 I will be a bit more pretentious and use "creation" where Dewey would have preferred "construction."

5 My conclusion presents Dewey as a gay scientist joining Nietzsche in making creative use of the genetic method. ${ }^{4}$ They also use the genetic method to keep track of what human inquiry has created even when it becomes "exapted" from its original purpose or function. ${ }^{5}$ All along the way, things will fall into place if we carefully distinguish the experience of existence from the cognitive linguistic meanings, identities, and essences we create from our experience. ${ }^{6}$

\section{Experience, Qualities, Metaphor, and Metonymy}

6 The Oxford English Dictionary defines "metaphor" as: "The figure of speech in which a name or descriptive term is transferred to some object different from, but analogous to, that to which it is properly applicable; an instance of this is a metaphorical expression." In his Rhetorik Nietzsche (1872-1873/1989) says of metaphor that it "does not produce new words, but gives a new meaning to them" (23). ${ }^{8}$ This is not very helpful since we are not that interested in words per se. He does cite Aristotle's famous definition approvingly: "a metaphor is the carrying over of a word whose usual meaning is something else, either from the genus to the species, from the species to the genus, from species to species, or according to proportion" (Rh: 55). However, as Alan D. Schrift (1990), indicates, Nietzsche breaks the bounds of Aristotle's restriction of metaphor to linguistic conveyance to

[...] regard any transference from one sphere to another (e.g., physical to spiritual, literal to figurative, audible to visual, subject to object, etc.) as an instance of metaphor. (126)

"Whereas every metaphor standing for a sensuous perception is individual and unique and is therefore always able to escape classification," according to Nietzsche (1873/1999), "the great edifice of concepts exhibits the rigid regularity of a Roman columbarium" (\$1). Thus, for Nietzsche, categories, concepts, identities, and kinds

[...] are only the left-over residue of a metaphor, and... the illusion produced by the artistic translation of a nervous stimulus into images is, if not the mother, then at least the grandmother of each and every concept. (\$1) 

from the body and employ it as a guide. It is the much richer phenomenon, which allows of clearer observation" (\$ 532). Drawing on Dewey’s embodied aesthetic, in The Meaning of the Body, Johnson boldly (2007) asserts: "Meaning is grounded in our bodily experience" (12). Schrift identifies a "three-stage metaphorical translation" from embodied empirical perception to logical conception in Nietzsche's texts (Schrift 1990: 126). Here are the first two stages:

The stimulation of a nerve is first translated into an image: first metaphor! The image, in turn is imitated in a sound: second metaphor! (Nietzsche, (1873/1999: §1)

The third metaphorical translation is from sound (e.g., word) to concept: "The word contains nothing but an image; from this comes the concept" (Nietzsche, 1979: §55). The second two phases of this embodied understanding of metaphor somewhat resembles that of Lakoff and Johnson (1999) and Johnson (2007), who conceive metaphors as a mapping of entities and relations from sensorimotor "image schemas" as source domains to abstract target domains. It nicely captures the hyphen in Dewey's hyphenated phrase "body-mind" (see LW 1: Ch. 7). ${ }^{9}$ Nietzsche (1979) observes, "this must be an artistic power, because it is creative. Its chief creative means are omitting, overlooking, ignoring." (\$55). ${ }^{10}$

We will find Dewey makes comparable moves. Finally, Nietzsche mentions, "metaphor is a shortened simile, as the simile as metaphor pleonazousa [metaphor being exaggerated]" (§55). We will be primarily interested in metaphor pleonazousa operating upon experienced qualities.

11 The Oxford English Dictionary (OED) defines metonymy as: "A figure of speech which consists in substituting for the name of a thing the name of an attribute of it or of something closely related."

12 Nietzsche (1872-1873/1989) defines metonymy as "the substitution of cause and effect" (25). Later he expands the definition:

Metonymy, the placement of one noun for another, also called hypollege [an interchange, exchange], cuius vis est, pro eo quod dicitur causam propter quam dicitur ponere [the substitution of the cause for which we say a thing in place of the thing to which we refer]. It is very powerful in speech: the abstract substantiva are qualities inside us and around us, which are torn away from their substrata and set forth as independent essences. (Nietzsche (1872-1873/1989: 59)

The reference to qualities, causation, and essences will engage us when we turn to Dewey. We will be especially interested in metonymy in the form of synecdoche, which the Oxford English Dictionary defines as:

A figure by which a more comprehensive term is used for a less comprehensive or vice versâ; as whole for part or part for whole, genus for species or species for genus, etc.

\section{Metaphor and Metonymy in the Creation of Identical Objects}

Nietzsche's stance arises from his commitment to Heraclitian becoming, which, according to the standard account of his development, emerges from his reading of the early field theorist Roger Boscovich, evolutionary theory (Ernst Haeckel and Wilhelm Roux), and the neo-Kantian F. A. Lange. On this account, Schopenhauer sways Nietzsche from philology to philosophy in the mid-1860's. He then works with a Kantian-Schopenhauerian 
structure that assumes a skeptical appearance versus reality dualism in which truth (concepts, etc.) necessarily falsifies reality (i.e., "the thing-in-itself"), which he never abandons. "On Truth and Lying" comes from his early period. With his reading of Lange especially, Nietzsche rejects Kant and Schopenhauer's metaphysics that emphasized logical and conceptual priority to a static world of things-in-themselves for a temporal, evolutionary, and physiological priority wherein chaos and becoming replace das Ding an sich, but he retains his pessimistic, dualistic epistemology. Such an account leaves Nietzsche at odds with Dewey.

However, there are problems with the received account that will become evident as we move forward. For one thing, there is Nietzsche's (1873/1998) "Philosophy in the Tragic Age of the Greeks," which was written in 1873, although never published in his lifetime. ${ }^{11}$ Here, we find Nietzsche already expressing Heraclitian views critical of Kant and Schopenhauer's metaphysical and moral interpretation of the world while exploring becoming, naturalism, and anti-dualism. My paper will show that like Dewey, Nietzsche eventually abandoned the appearance versus reality dualism of not only of Kant, but also Lange, and with it the skeptical view of truth as falsifying reality. However, truth remains a "mobile army of metaphors, metonyms, and anthropomorphisms" because all meanings, essences, and values are human creations. There are no metaphysical world of

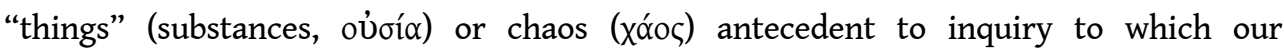
constructions correspond. There is just existence as we experience it and what we make of it. What is crucial is that we distinguish existence and essence without constructing a distorting dualism between them.

Every individual, every particular is unequivocally unique in its existence. We construct identity from similarities by ignoring differences that might matter given other perspectives and purposes:

Every concept comes into being by making equivalent what is non-equivalent. Just as it is certain that no leaf is ever exactly the same as any other leaf, it is equally certain that the concept "leaf" is formed by dropping these individual differences arbitrarily, by forgetting those feature which differentiate one thing from another, so that the concept then gives rise to the notion that something other than leaves exists in nature, something which would be "leaf," a primal form, say, from which all leaves were woven... (Nietzsche, 1873/1999: \$1)

17 The process is "anthropomorphic through and through" (\$1). According to Nietzsche, nothing ever occurs twice empirically. ${ }^{12}$ Nietzsche is influenced by Heraclitus:

Heraclitus somewhere says that all things are in process and nothing stays still, and likening existing things to the stream of a river he says that you would not step twice into the same river. (Plato, Cratylus 402a; see KR, 197)

Similar remarks hold for leaves. "Like form," Nietzsche (1873/1999) concludes, "a concept is produced by overlooking what is individual and real" $(\S 1){ }^{13}$

Nietzsche (1901/1967) insists that the identity of objects is something made, not found:

It is we who created the "thing," the "identical thing," subject, attribute, activity, object, substance, form, after we had long pursued the process of making identical, course and simple. (§ 521)

Again,

Before there is "thought" there must have been "invention," the construction of identical cases, of the appearance of sameness is more primitive than the knowledge of sameness. (§544) 
It will become clear that for Dewey, the identity of objects is a creative product of the process of inquiry.

Dewey understands the limits of language when confronted by the richness of experience as well as Nietzsche:

A universe of experience is the precondition of a universe of discourse... The universe of experience surrounds and regulates the universe of discourse but never appears as such within the latter. (LW 12: 74)

\section{He remarks:}

Language comes infinitely short of paralleling the variegated surface of nature. Yet words as practical devices are the agencies by which the ineffable diversity of natural existence as it operates in human experience is reduced to orders, ranks, and classes that can be managed... The unique quality of a quality is found in experience itself; it is there and sufficiently there not to need reduplication in language. The latter serves its scientific or its intellectual purpose as it gives directions as to how to come upon these qualities in experience. (LW 10:219)

The transfer from the sensuous qualities of existential experience to linguistic meanings and logical essences involves the use of metaphor, especially synecdoche and simile; that is, taking a part (language and logic) for the whole of human experience. ${ }^{14}$

Like Nietzsche's leaf, Dewey insists the sensuous perception of immediate anoetic existential quality never recurs exactly the same twice:

Such immediate qualities as red and blue, sweet and sour, tone, the pleasant and unpleasant, depend upon an extraordinary variety and complexity of conditioning events; hence they are evanescent. They are never exactly reduplicated, because the exact combination of events of which they are termini does not precisely recur. (LW 1: 95)

Recurrent identity is only a functional equivalence within a discursive system: "No quality as such occurs twice. What recurs is the constancy of the evidential force of existences which, as occurrences, are unique" (LW 12: 319). Identity is the product of a creative process.

Let us follow Dewey's genetic trace of the creation of identical objects as instances of a kind from its origins in sensuous qualitative experience. When we are done, we will see why he says:

The name objects will be reserved for subject-matter so far as it has been produced and ordered in settled form by means of inquiry; proleptically, objects are the objectives of inquiry... For things exist as objects for us only as they have been previously determined as outcomes of inquiries. (LW 12: 122)

Dewey thinks the identity of objects is something made not found.

Dewey condemns what he calls "the philosophic fallacy" by which he means the "conversion of eventual functions into antecedent existence" whether performed on "behalf of mathematical subsistences, esthetic essences, the purely physical order of nature, or God" (LW 1: 389). By functions, Dewey means something having a determinate function within inquiry such as being data, characteristic traits, properties, and objects of a kind. Such production is a creative activity. In his 1938 Logic, he indicates: "In the early history of Greek reflective thought, art, or techne, and science, were synonymous" (LW 12: 77). Recall that for the ancient Greeks, techne was the form of skilled knowledge of poiesis (making, creating, calling into existence). Nietzsche and Dewey would like us to return to these classical connotations. Dewey explicitly rejects the theory versus practice dualism 
and insists that all reason is practical reason: "Rationality as an abstract conception is precisely the generalized idea of the means-consequence relation as such" (LW 12: 17). ${ }^{15}$ In our conclusion, we will call Dewey's genetic production account "gay science."

Let us concentrate on the creation of objects as instances of kinds. Realists assume kinds are natural if their classifications, taxonomies, and so on correspond to antecedently existing, fixed, and final groupings of substances in nature apart from human practices. They commit "the philosophic fallacy." Like Nietzsche, Dewey famously rejected the metaphysical correspondence theory of truth. According to Nietzsche (1878/1986),

[...] Logic too depends on presuppositions with which nothing in the real world corresponds, for example on the presupposition that there are identical things, that the same thing is identical at different points of time. (Vol. I: \$ 11)

Nietzsche and Dewey are pluralistic perspectival empirical naturalists who reject mental representations as mirrors of nature.

Dewey explicitly discards the appearance versus reality dualism in "The Postulate of Immediate Empiricism" (MW 3: 158-67). Nietzsche (1889/2005) does the same in "How The 'True World' Finally Became a Fable" (171). Both dismiss the spectator stance that places a veil of representations between the knower and the known for a participant stance where the knower becomes a participant in the events of existence and creators not discoverers of meaning and value.

We do not have room to examine both of these breakthrough texts. Clark (1990: 95-125) shows that at least the last four of the six stages Nietzsche delineates provides a description of Nietzsche's own epistemological development. Since he arrives at the same extraordinarily original place as Dewey, we will trace the outline of Nietzsche's development upon a path few western philosophers have ever traversed.

Nietzsche (1889/2005) delineates six stages. Plato and then Christianity typify the first two (171). The third is characterized by Kantianism and portrays Nietzsche's own position when he embraced Schopenhauer: "The real world, unattainable, indemonstrable, cannot be promised, but even when merely thought of a consolation, a duty, an imperative" (171).

35 At this stage, the metaphysical quest for certainty remains an epistemic and moral duty, although we can never hope to complete it. Following Kant, Nietzsche assumes genuine objective "Truth" requires correspondence to metaphysical reality in itself; hence, merely empirical human knowledge necessarily falsifies reality. This is Nietzsche's stance when he wrote "On Truth and Lying," although he was already flirting with a Heraclitian critique. Positivism exemplifies the fourth state:

The real world - unattainable? Unattained, at any rate. And if unattained also unknown. Consequently also no consolation, no redemption, no duty: how could we have a duty towards something unknown? (171)

Clark identifies this stage with Nietzsche when he wrote Human, All to Human. Here, Lange's temporal chaos becomes the thing-in-itself while the naturalistic priority of evolutionary physiology replaces the priority of Kant's categories and concepts. "Truth" remains an illusion or fiction because our concepts (or if you prefer our linguistic terms) fail to correspond to metaphysical reality (see Clark 1990: 79, 121-2). Stack places Lange's influence earlier, given developmental continuity, we do not need to be too precise about transitions (Stack 1983: 94ff.). In any case, Lange's influence is clearly present in stage 5: "The 'real world' -- an idea no longer of any use, not even a duty any longer - an idea grown useless superfluous, consequently a refuted idea: let us abolish it!" (Nietzsche 
1889/2005: 171). Clark correctly identifies this stance with Nietzsche when he wrote Gay Science and Beyond Good and Evil. The metaphysical world vanishes leaving us with a world of sensuous appearance. There is no thing-in-itself to which our concepts may refer (see Clark 1990: 112). As Wilcox remarks, Nietzsche seems to assume that "a statement with existential import is false if the existential commitment is false" (Wilcox 1986: 352). ${ }^{16}$

Clark insists "Stage 5 does not bring to an end the 'longest error' because its devaluation of 'this' world makes sense only if it ascribes 'true being' to another world" (Clark 1990: 113). Thus we are led to the "INCIPIT ZARATHUSTRA" of stage 6:

We have abolished the real world: what world is left? The apparent world perhaps? ... But no! with the real world we have also abolished the apparent world! (Nietzsche, 1889/2005: 171)

$$
\begin{aligned}
& \text { and conceptual perspectives. All cognitive comprehension is entirely interpretative. } \\
& \text { While the noumenal world will always remain a conceivable possibility, to the pleasure of } \\
& \text { radical skeptics, it is a nomic impossibility for the more optimistic or at least meliorist } \\
& \text { perspectival empiricist. Indeed, we derive even abstract conceptual possibilities our } \\
& \text { perspective as finite human beings. There are no perceptions from nowhere; likewise, } \\
& \text { there are no God's eye view or even the perspective from everywhere: } \\
& \text { We cannot look around our corner: it is a hopeless curiosity to want to know what } \\
& \text { other kinds of intellects and perspectives there might be... But I think that today we } \\
& \text { are at least far away from the ridiculous immodesty of decreeing from our angle } \\
& \text { that perspectives are permitted only from this angle. Rather, the world once again } \\
& \text { has become infinite to us: insofar as we cannot reject the possibility that it includes } \\
& \text { infinite interpretations. (Nietzsche } 1882 / 1974: \S 374 \text { ) }
\end{aligned}
$$
terests, and desires. Our finite purposes penetrate both our perceptual 
to comprehend or judge reality as a totalized whole (including the concept of the nominal world), because we can only comprehend it from our finite human perspectives.

Once we drop the notion that representations are an opaque screen separating us from reality, we may abandon what Dewey calls the "spectator theory" (LW 4: 19, 163, 195) for a stance wherein human nature is simply another natural event participating among an endless array of other events. We may also abandon the epistemological quest for certainty (LW 4). Knowledge (Dewey preferred the phrase "warranted assertion") is simply something humans create from their experience of existence that allows them to survive, thrive, and delight in their own existence. Not just falsifiable, such knowledge is as contingent as are its creators.

Nietzsche and Dewey disparage the notion that experience is a "veil or screen which shuts us off from nature" (LW 1: 11). Before overcoming the veil of representations sealing us off from reality, Dewey indicates, we assumed "a reality in Being independently of the operations of inquiry is the standard and measure of anything said to be known" (LW 4: 161). The essential difference for Nietzsche and Dewey is that

[...] between a mind which beholds or grasps objects from outside the world of things, physical and social, and one which is a participant interacting with other things and knowing them provided the interaction is regulated in a definable way. (LW 4: 160)

Once we abandon the spectator theory, we may realize that

[...] any cognitive conclusion depends upon the method by which it is reached, so that the perfecting of method, the perfecting of intelligence, is the thing of supreme value (LW 4: 160)

$$
\text { "cosmos as fact" (LW 16: 58). Frank X. Ryan reminds us of two things that help us better }
$$
understand what Dewey and Bentley mean. He calls attention to this observation:

That Fact is literally or etymologically something done or made has also the advantage of suggesting that the knowing and identifying, as ways of acting, are as much ways of doing, of making... as are chopping wood, singing songs, seeing sights or making hay. (LW 16: 54)

Ryan further indicates, "the Greek word kosmos originally meant a world made intelligible as order is brought from chaos" (Ryan 2011: 50). Of course, having abandoned the appearance versus reality dualism, we may also overcome the chaos versus cosmos dualism and simply say that a cosmos is whatever we have made that is intelligible to us from our human participatory perspective. The rest is chaos only because if defies are comprehension. As Nietzsche states:

The total character of the world, however, is in all eternity chaos - in the sense not of a lack of necessity but a lack of order, arrangement form, beauty, wisdom, and whatever other names there are for our aesthetic anthropomorphisms. (Nietzsche, 1882/1974: § 109) 

involves an intrusion of our anthropomorphic purposes. Nietzsche would approve:

Our utterances by no means wait until our perception and experience have provided us with a many-sided, somehow respectable knowledge of things; they result immediately when the impulse is perceived. Instead of the thing, the sensation takes in only sign. That is the first aspect: language is rhetoric...(Nietzsche, 1872-1873/1989: § 23)

The extraneous use of qualitative experiences or images as signs is the primordial source of data for the construction of the identity of objects as instances of a kind. It is also an instance of a metaphor moving from a sensuous image (Nietzsche) or quality (Dewey) as 
the source domain to semiotics as the target domain. Said differently, we create things by making and using signs.

The ultimate context for any inquiry is some disrupted, doubtful, indeterminate qualitative situation in which we are participants:

[A] situation is a whole in virtue of its immediately pervasive quality. When we describe it from the psychological side, we have to say that the situation as a qualitative whole is sensed or felt. Such an expression is, however, valuable only as it is taken negatively to indicate that it is not, as such, an object in discourse. (LW 12: 73-4)

61 This is important because:

That which is "given" in the strict sense of the word "given," is the total field or situation. The given in the sense of the singular, whether object or quality, is the special aspect, phase or constituent of the existentially present situation that is selected to locate and identify its problematic features with reference to the inquiry then and there to be executed. In the strict sense, it is taken rather than given. This fact decides the logical status of data... It embodies a fixation of the problem in a way which indicates a possible solution. It also helps to provide evidence. (LW 12: 127)

62 We must have something intuitively, anoetically given; no one creates ex nihilo. Taking a part (data) for a whole (total field) is an instance of a synecdoche. In a synecdoche, Nietzsche (1872-1873/1989) perceives, "A partial perception takes the place of the entire and complete intuition" (23). Data, evidence, and such are all synecdoches.

"For purposes of theory," Dewey finds,

the important consideration is that existent things, as signs, are evidence of the existence of something else, this something being at the time inferred rather than observed. (LW 12: 58)

64 As such, we may use them to carry out logical inferences for practical purposes that anthropomorphically involve embodied habits. We may become reflectively aware of our habits and begin to control them to make dependable conclusions. When this occurs, the "idea of a method of inquiry arises as an articulate expression of the habit that is involved in a class of inferences" (LW 12: 19-20). If we can linguistically state the habit of inference, we may embark on consciously controlled inquiry toward creating the objects that "are the objectives of inquiry" (LW 12: 19-20).

Such qualitative data creatively taken from a larger qualitative whole eventually decides the identity of objects as instances of natural kinds. Qualities as such never recur; what "recurs is the constancy of the evidential force of existences which, as occurrences, are unique" (LW, 12: 319). This is the force of qualitative data taken and creatively used as evidential signs:

When we say "characteristic trait" we mean precisely that a specified quality is such as to serve as a diagnostic mark, an evidential sign, of the presence of an object of a specified kind. (LW 11: 96)

66 A kind is simply a conjunction of descriptive traits: "Qualities which descriptively determine (distinguish and identify) kinds, I shall indifferently call traits or characteristics " (LW 12: 259).

67 Critical to the process of inquiry is the "determination of the differential traits which are evidential signs of one and not another kind" (LW 12: 196). Dewey concludes: "A conjunction of traits or a description is the basis of institution of a kind" (LW 12: 240). ${ }^{19}$ 
Kinds are tropological creations along the genetic path to the creation of identical objects.

Every trait is a quality, but only those qualities selectively discriminated from a total field or situation to function as a sign in inference is a trait: "From the standpoint of existence, independently of its subjection to inquiry, there is no criterion. Everything in the world is like everything else in some respects, and is unlike anything else in other respects" (LW 12: 267). Existentially, every simile succeeds, although it may fail for the purposes of a given inquiry. Consider Dewey's example:

[T]here are persons who have the quality of being cross-eyed, of being bald and being shoemakers. Why not form a kind on the basis of these qualities? The answer is that such a set of conjoined traits is practically worthless for the purpose of inference. (LW 12: 267)

Here, the simile as metaphor pleonazousa does not work practically for the evidential purposes of Dewey's imagined inquiry. ${ }^{20}$ Nonetheless, when it does work, we have an important instance of the contribution of metaphor to the construction of the identity of objects as one of a kind, along with propositional attitudes regarding them. "To hold that cognition is recognition," Dewey elsewhere concludes, "is to concede that likeness, a relation, rather than existence, is central" (LW 1: 249).

The following sums up the movement from a given qualitative existential whole, to qualia selected as evidential data as characteristic traits for inference, to an essential property we may predicate of objects:

We are thus enabled to make definite the logical differences between quality, characteristic trait, and property... "Turning paper red," is, as the object of a particular observation, a quality. As enabling reasonably safe inference to be made as to the occurrence of other qualities under certain conditions, it is a distinguishing trait or characteristic descriptive of a kind. It becomes a property when it is determined by negative as well as positive instances to be a constant dependable sign of other conjoined characteristics. It then belongs inherently to all cases of the kind. (LW 12: 292)

71 Here, the simile succeeds practically. ${ }^{21}$ Blue and red are existential qualities. If we perform the chemical existential operation of placing blue litmus paper into a solution and it turns red, the results provide a strong evidential sign of acidic conditions. In chemistry, the property " $\mathrm{pH}$ " is a precise measurement signifying whether a solution is an acid or base. An acid has the property of a $\mathrm{pH}$ less than $7 .{ }^{22}$

Dewey distinguishes between two kinds of generalization. Generic propositions refer to kinds and have existential spatial-temporal connections. They function in inquiry to organize perceptual materials as evidence. Thus far, we have only considered some of the things that go into the construction of genetic propositions. Universal propositions lack existential import; they may prove valid even when nothing exists to provide them content. They function in inquiry to propose possible stable and repeatable operations that, if successful, allow us to resolve problematic situations. The determination of operations involves an abstract universal:

From the point of view of what has been said, every universal, like any rule, is a formulation of an operation to be performed. A universal does not claim to describe; description is in terms of the conjunction of qualities that enable us to discriminate and identify the kind of which a thing is. (LW 11:107) Ideas, universals, and the like direct the inventive operations that determine some object as an instance of a kind. 
74 For Dewey, facts, data, and characteristic traits arise as a consequence of the operations of inquiry carried out for our practical anthropomorphic purposes.

What is meant by calling facts operational? Upon the negative side what is meant is that they are not self-sufficient and complete in themselves. They are selected and described, as we have seen, for a purpose... (LW 12: 116-7)

Initially, this is a matter of comparatively noting similarities and differences:

Now it is impossible to define comparison except operationally... It is a name for any and all of the operations by means of which alleged or provisional data are determined to be data with respect to the problem set by a given indeterminate situation... (LW 12: 184-5)

If the data is mis-taken, then inference will almost assuredly fail. Furthermore,

[...] comparison obviously involves selection-rejection, for objects and events cannot be compared in toto. The positive import of this fact is that in order to be compared, subject-matters must be reduced to "parts": that is, to constituents that are capable of being treated as of the same kind or homogeneous. To compare is to pair, and things that are paired are thereby made commensurate with respect to carrying out some operation in view. (LW 12: 203)

Comparison establishes analogies and disanalogies, which involve metaphors, metonyms, and anthropomorphisms. The operation of reducing wholes to parts obviously employs synecdoche; "selection-rejection" is perspectival.

We cannot make the distinction between generic and universal propositions merely by inspecting the linguistic form of a proposition. Their difference rests on a more basic distinction between particular and singular propositions. A namable particular is the spatial and temporal existential quality (red, blue, sweet, or sour) within an anoetically intuited larger existential qualitative whole. However, 'the logical import of a 'particular' is determined by the strictly limited local and temporal occurrence of the quality in question" (LW 12: 291).

Particular propositions, however, are linguistically stable and repeatable:

Propositions of the kind called particular represent the most rudimentary form of propositions of subject-content. They are propositions which qualify a singular, this, by a quality proceeding from an operation performed by means of a sense organ. (LW 12: 289)

Data (i.e., evidential signs used for inference) first find linguistic expression as particular propositions. For example, "this is red" or "this is sweet." ${ }^{23}$ It is a sensory synecdoche where experience serves as the source domain and language the target. ${ }^{24}$

"The singular is described (discriminated and identified) as one of a kind," according to Dewey,

[...] by means of a conjunction of traits which make it like certain other things already determined and that are likely to occur for determination in the future. (LW 12: 246)

Here, we have a metaphor (specifically, a simile) whereby linguistic descriptions stand for sensuous perception that is unique, one-time-only, and escapes classification. What recurs is the kind as a conjunction of descriptive traits arising from systematic, stable, and repeatable operations (see LW 12: 247). Dewey deliberately eschews the notion that such kinds are immutable "eternal essences" (i.e., substances) that supervene on experience a priori. They are contingent a posteriori creations. 

ular propositions most commonly take the form of "sugar is sweet" having some specific object, thing, substance, and such as the subject term and a quality in the predicate term. However, sometimes an ambiguity of linguistic structure makes particular and singular propositions formally indistinguishable. Dewey exposes this ambiguity to clarify the difference between the two kinds of propositions:

Singular propositions are such as determine this to be one of a kind. Take the two possible meanings of "This is sweet." When the proposition is particular, it indicates... an immediate [existential] change that has occurred or is about to occur. The same expression when it presents the solution of a problem, means that "this" is one of the kind of sweet things: or that this has the potentialities which are properties of any sweet thing. The sweet quality is no longer simply a change which has occurred; it is a sign of a conjoined set of consequences that will occur when certain interactions take place. (LW 12: 291)

Dewey's example is a lightning flash:

The flash is certainly not recurrence in the sense of re-appearance of an object or event which has presented itself before and which has endured in existence during the interval. Clearly, the recurrence here is practically synonymous with identification of the flash as one of a kind. (LW 12: 247)

Each flash of lightning is existentially unique and one time only whereas the essence of the kind may reappear. "Identification" here as Larry Hickman says,

[...] indicates a way of making something into something else. To put this another way, it is the use of something as a sign to signify some further thing. (Hickman 1990: 127-8)

The making of something into something else is primordial rhetorical poiesis.

Dewey asks us to consider the difference between the morning star and evening star:

For in any case, the experience is unique and non-recurrent. On what grounds do we draw a distinction between its unique character and the identity of the object which is its subject-matter? (LW 12: 248)

Experience does not give the identity of the morning star and evening star. It is a matter of evidential data, inference, and the contingent construction of kinds; hence:

The only conclusion which can be drawn for logical theory from these considerations is that the problem of the sameness of the singular object is of the same logical nature as the problem of kinds. Both are products of the continuity of experiential inquiry. Both involve mediating comparisons yielding exclusions and agreements and neither is a truth or datum given antecedent to inquiry. They are not only products of the same operations of inquiry but are bound up together. The determination that a singular is an enduring object is all one with the determination that it is one of a kind. The identification of a sudden light as a flash of lightning, of a noise as the banging of a door, is not grounded upon existential qualities which immediately present themselves, but upon the qualities with respect to the evidential function or use in inquiry they subserve. What is recurrent, uniform, common, is the power of immediate qualities to be signs. (LW 12: 248)

Avoiding "the philosophic fallacy" requires recognizing that the taking of signs to create the identity of objects as instances of a kind depends upon commanding a mobile army of metaphors, metonyms, and anthropomorphisms. 


\section{Metaphor and Metonymy in the Creation of Free Will, Causation, and Necessity}

Recall Nietzsche's definition of metonymy in his Rhetorik. Let us consider two of his examples. The first concerns the human property or essence of "courage":

The audacia [courage] causes men to be audaces [courageous]; at bottom, this is a personification, like that of the Roman concept-gods... These concepts, which owe their origin only to our experiences, are proposed a priori to be the intrinsic essences of the things: we attribute to the appearances as their cause that which still is only an effect. The abstracta evoke the illusion that they themselves are these essences which cause the qualities, whereas they receive a metaphorical reality only from us, because of those characteristics. (Nietzsche 1872-1873/1989: 59)

This passage portends Nietzsche and Dewey's discussion of free will below. It also hints at "the philosophic fallacy." The following is the most famous instance of the fallacy in the history of Western thought:

The transition from the eide [originally, shape or form of that which is seen] to ideai [ideal forms] by Plato is instructive; here, metonymy, the substitution of cause and effect is complete. (59)

2 Here, an eventual function of creative human inquiry, the empirical eide, is hypostatized, reified, and then converted into a putatively antecedently existing higher order eternal and immutable metaphysical ideai. In a dramatic reversal, Plato uses the higher ideai to provide causal explanations of the lower, contingent, changing, and imperfect eide whence they originally derived. This endlessly recurring pattern characteristic of western ontotheology depends on a failure to carefully distinguish our experience of existence from the essences we create from it. ${ }^{25}$

Putative causes are imaginary anyway. Nietzsche explores, "The error of false causality":

We believed ourselves to be causal agents in the act of willing; we at least thought we were catching causality in the act. It was likewise never doubted that all the antecedentia of an action, its causes, were to be sought in the consciousness and could be discovered there if one sought them as motives: for otherwise one would not have been free to perform it, responsible for it. Finally, who would have disputed that a thought is caused? That the ego causes the thought. (Nietzsche,1889/2005: 59-60)

94 Nietzsche thinks our notions of causation are anthropomorphic; so does Dewey:

Labor and the use of tools seem, however, to be a sufficient empirical reason: indeed, to be the only empirical events that can be specifically pointed to in this connection. They are more adequate grounds for acceptance of belief in causality than are the regular sequences of nature or than a category of reason, or the alleged fact of will. (LW 1: 73)

5 We saw in the last section that logical labor produces data, characteristic traits, and objects as instances of a kind. It involves the skilled use of tools (instruments, an organon, etc.), including the tropological use of language as well as logic and other instruments of observation and experimentation. Causation is also an instance of poiesis requiring techne. Labor involves transaction with the world. We should not confine it to "inner" thought, a category of reason, or free will.

Nietzsche (1889/2005) finds a psychological explanation for metonymy in cause-effect thinking that arises from human need and desire: 
Familiarizing something unfamiliar is comforting, reassuring, satisfy, and produces a feeling of power as well. Unfamiliar things are dangerous, anxiety-provoking, upsetting, - the primary instinct is to get rid of these painful sates... The first consequence of this need is that causation gets attributed to something we are already familiar with, something we have already encountered and registered in memory. This forecloses the possibility that anything novel, alien, or previous unencountered can be a cause. - So, we are not looking for just any type of explanatory cause, we are looking for a chosen, preferred type of explanation. (Nietzsche 1889/2005: 180)

In Dewey's words:

To explain is to employ one thing to elucidate, clear, shed light upon, put in better order, because in a wider context, another thing. It is thus subordinate to more adequate discourses, which applied to space-time affairs, assume the style of narration and description. Speaking in terms of captions familiar in rhetoric, exposition and argument are always subordinate to a descriptive narration... (LW 1: 216)

Causal explanation involves the arts of rhetoric. We do not simply explain something; we explain something to somebody. Ultimately, we explain something to the linguistic communities in which we participate (e.g., technosciences, politics, academia, business, etc.).

9 The following expands Nietzsche's criticism of the concept of causation to natural science:

One should not wrongly reify "cause" and "effect," as the natural scientists do... according to the prevailing mechanical doltishness which makes the cause press and push until it "effects" its end; one should use "cause" and "effect" only as pure concepts, that is to say, as conventional fictions for the purpose of designation and communication - not for explanation. In the "in-itself" there is nothing of "causal connections," "of necessity," or of "psychological non-freedom": there the effect does not follow the cause, there is no rule of "law."(Nietzsche, 1886/1966: § 21)

Elsewhere, he insists: "Necessity is not a fact but an interpretation" (Nietzsche 1901/1967: $\S 552)$. It is easy to follow Nietzsche here if we simply make the distinction between existence and essence. Once we do, all substances including causation, audacia, necessity, God, Rationality, and so on will all seem pretty much the same; they are the result of a rhetorical process that has evolved into reified hypostatic abstractions.

While useful, analytically distinguishing cause from effect in the course of logical inquiry involves separating in thought an existentially continuous temporal process. The following passage is from the chapter on "Scientific Laws" in Dewey's 1938 Logic:

The term "causal laws" is... a figure of speech. It is a case of metonymy in which a law is designated not in terms of its own content but in terms of consequences of execution of its function. By use of such a figure of speech, a rod of metal is called a lever; a particular arrangement of a piece of wood and metal is called a hammer; a visible white material phenomenon is called sugar, etc., etc. As has been previously noted, even the objects of [commonsense] experience are habitually designated in terms of the potential consequences of their familiar interactions with other things. Common sense, however, is given to ascribing these consequences to some "power" inherent in the things themselves (an ingredient of the popular notion of substance), and to ignoring interaction with other things as the determining factor. (LW 12: 440)

2 Calling causal laws, and everyday objects a metonymy is to explicitly acknowledge the role of poiesis and rhetoric in the logical construction of causation as well as objects like levers and hammers. 

something deliberately taken and crafted for our purposes:

[C]ausation as ordered sequence is a logical category, in the sense that it is an abstract conception of the indefinitely numerous existential sequences that are established in scientific inquiry: - established by means of the use of generalized propositions as laws. For when events are taken strictly existentially, there is no event which is antecedent or "cause" any more than it is consequent or "effect"... An event has to be deliberately taken to be cause or effect. Such taking would be purely arbitrary if there were not a particular and differential problem to be solved. (LW 12: 453)

Causation is a logical creation with many tropological components carried out for the practical purpose of coordinating problematic situations.

We create a cause and effect series from the otherwise meaningless events of existence. Once again, the decisive distinction is that between existence and the essences we create from existence for our perspectival purposes. As long as we do not reify our anthropomorphic abstractions as eternal, immutable essences, it should generate no confusion. Our creations are part of "reality"; they are enduring, but not eternal. In The Gay Science, Nietzsche observes:

Cause and effect. - "Explanation" is what we call it... We have uncovered a manifold one-after-another where the naïve man and inquirer of older cultures saw only two separate things... In every case the series of "causes" confronts us much more completely, and we infer: first, this and that has to precede in order that this or that may then follow - but this does not involve any comprehension. In every chemical process, for example, quality appears as a "miracle," as ever. (Nietzsche (1882/1974: § 112)

In "The Evolutionary Method as Applied to Morality," Dewey asks us to consider that hydrogen and oxygen coming together has the "effect" of producing water. Before coming together, "they are absolutely unknown" (MW 2: 12). We can only "know them through and in a process, exactly as analyzing water into them explains water in genetic terms" (MW 2: 12). Philosophers fail to realize this,

[...] because an older purely metaphysical conception of causation survives according to which the cause is somehow superior in rank and excellence to the effect. The effects are regarded as somehow all inside the womb of cause, only awaiting their proper time to be delivered. They are considered as derived and secondary, not simply in the order of time, but in the order of existence. (MW 2: 12) Like objects, cause and effect relations are temporally emergent products of inquiry wherein the cause only arises with its effect.

For Dewey cause and effect is the product of processes that we may only comprehend using historical method. Dewey writes:

The simple fact of the case is that the genetic method, whether used in experimental or historical science, does not "derive" or "deduce" a consequent from an antecedent, in the sense of resolving it, or dissolving it, into what has gone before. The later fact in its experienced quality is unique, irresolvable, and underived. Water is water with all its peculiar characteristics, after the presence of oxygen and hydrogen gas has been shown to be a necessary condition of its generation as much as before. (MW 2: 10-12) ${ }^{26}$

The genetic method allows us to better control the appearance and disappearance of experienced qualities and connect them to other qualities that appear and disappear in a 
series of reactions. Dewey might have said, "In every chemical process... quality appears as a 'miracle,' as ever” (Nietzsche 1882/1974: § 112).

Nietzsche agrees with Dewey that the dualism of cause and effect leads to confusion; he also agrees about the indefiniteness of logical sequences we could create from the continuum of experience:

Cause and effect: such a duality probably never exists; in truth we are confronted by a continuum out of which we isolate a couple of pieces, just as we perceive motion only as isolated points and then infer it without ever actually seeing it... An intellect that could see cause and effect as a continuum and a flux and not, as we do, in terms of an arbitrary division and dismemberment, would repudiate the concept of cause and effect... (Nietzsche 1882/1974: § 112)

111 Nietzsche and Dewey understand natural existence as a qualitative Heraclitian flux whence we create meanings and values. We must realize that out of an infinite number of ongoing existential events, we finite beings perspectivally select only a few aspects for our practical purposes of predicting and controlling events:

An event has to be deliberately taken to be cause or effect. Such taking would be purely arbitrary if there were not a particular and differential problem to be solved. Given the problem of resolving a gross and indeterminate succession of observed qualitative events into a single continuous history, there is sufficient and necessary ground for taking one event as "effect" or consequent, and some other as antecedent or "cause." (LW 12: 454)

113 The cause and effect series we are most likely to construct from the vast continuum of experience are those allowing us to familiarize something unfamiliar.

114 Dewey assails necessity as much as causation. In "Superstition of Necessity," Dewey announces that "necessity" is logical not metaphysical; it has

[...] relevancy only with reference to the development of judgment, not with reference to objective things or events... [I]t refers to the content of that affirmation, expressing the degree of coherence between its constituent factors. (EW 4: 19-20)

115 What is necessary and what is contingent depends on what we abstract from experience and where we are in a given inquiry. The following brings Dewey's emphasis on reason as practical means-ends connections to the fore:

Contingent and necessary are thus the correlative aspects of one and the same fact: conditions are accidental so far as we have abstracted a fragment and set it up as the whole; they are necessary the moment it is required to pass from this abstraction back to the concrete fact. Both are teleological in character contingency referring to the separation of means from end, due to the fact that the end having been already reached the means have lost their value for us; necessity being the reference to an end which has still to be got... Note that the necessity of the means has reference to an end still to be attained, and in so far itself hypothetical or contingent, while the contingent circumstances are no longer needed precisely because they have resulted in a definite outcome... and we begin to see how completely necessity and chance are bound up with each other. (EW 4:29) ${ }^{27}$

116 The relation of parts to wholes (mereology) here is tropological. Necessity and contingency like cause and effect is teleological in character; both depend on human purposes and creativity.

117 Dewey devotes only one paragraph to causation in "Superstition," but it is worth citing since it expresses causation's anthropomorphic character: 
It is but another instance of the supreme importance of our practical interests. The effect is the end, the practical outcome, which interests us; the search for causes is but the search for the means which would produce the result. We call it "means and end" when we set up a result to be reached in the future and set ourselves upon finding the causes which put the desired end in our hands; we call it "cause and effect" when the "result" is given, and the search for means is a regressive one. In either case the separation of one side from the other, of cause from effect, of means from end, has the same origin: a partial and vague idea of the whole fact, together with the habit of taking this part (because of its superior practical importance) for a whole, for a fact. (EW 4: 36)

\section{Conclusion: Gay Science and the Genetic Method}

119 By now, it is easy to recognize that Dewey shares Nietzsche's devotion to gay science. Dewey writes: "Scientific inquiry is an art, at once instrumental in control and final as a pure enjoyment of mind" (LW 1: 9). Again, "science itself is but a central art auxiliary to the generation and utilization of other arts" (LW 10: 33). Elsewhere, he remarks that

[...] art, the mode of activity that is charged with meanings capable of immediately enjoyed possession, is the complete culmination of nature, and that science... conducts natural events to this happy issue. (LW 1:269)

\section{Dewey further states}

Thinking is preeminently an art; knowledge and propositions which are the products of thinking are works of art, as much so as statuary and symphonies. (LW $1: 283)$

Gay science creates tentative, falsifiable, and contingent "warranted assertions" much as we make pictures and poems.

Nietzsche and Dewey deploy the genetic method. One likely source of the method for both was the evolutionary theories of the nineteenth century:

Genetic method was perhaps the chief scientific achievement of the latter half of the nineteenth century. Its principle is that the way to get insight into any complex product is to trace the process of its making, - to follow it through the successive stages of its growth. (MW 9: 222)

Nietzsche's failure to follow Darwin led him into such vitalistic errors as "the will to power." ${ }^{28}$ Remarking on his contributions to Studies in Experimental Logic, expresses the following regret:

One of the points which gave much offense in the essays was the reference to genetic method - to a natural history of knowledge... I was to blame for not making the point more explicit. (MW 10:361)

Indeed, he uses the phrase dozens of times in different places to describe his method, although he does more frequently use "instrumentalism."

In the genetic method everything continuously emerges, evolves, and eventually eviscerates. Later, Dewey came to use the phrase "genetic-functional." For instance, he insists upon the

[...] compound word "genetic-functional" to describe what I regard as the proper method of philosophy is, then, directly linked to the position taken regarding the temporal continuum. (LW 14: 147) ${ }^{29}$ 
For Dewey, there were no absolute existential beginnings, merely places our inquiries reach their limit within a temporal continuum. ${ }^{30}$ Inside Dewey's genetic-functional method, facts (data, characteristic traits, and so on), habits of inference, kinds, properties, cause and effect, essences (entities, objects, ontology), genetic and universal propositions, ends-in-view (that is, ideals of action), ideas, norms, theories, symbols, the mental, the material, and much more are all subfunctions we construct within an emergent and temporal development. ${ }^{31}$ As such, our creations remain not only permanently falsifiable, but also contingent. They are all evolving events, not eternal entities - or, rather, what we call entities (concepts, ideas, ideals) are very stable, slowly moving events. Created, these contracted events emerge and evolve in the course of human inquiry that is the ongoing conversation of humankind.

\section{BIBLIOGRAPHY}

Clark M., (1990), Nietzsche on Truth and Philosophy, Cambridge, Cambridge University Press.

cox C., (1999), Nietzsche: Naturalism and Interpretation, Berkeley, University of California Press.

CRICK N., (2010), Democracy \& Rhetoric: John Dewey on the Arts of Becoming, Columbia, The University of South Carolina Press.

DANTo A. C., (1965), Nietzsche as Philosopher, New York, The Macmillan Company.

DE MAN P., (1975), “Action and Identity in Nietzsche,” Yale French Studies 52, 16-30.

DEWEY J., EW, (1969-1972), The Early Works of John Dewey, 1882-1898, ed. by J. A. Boydston, Southern Illinois University Press, Carbondale and Edwardsville.

DEWEY J., MW, (1976-1983), The Middle Works of John Dewey, 1899-1924, ed. by J. A. Boydston, Southern Illinois University Press, Carbondale and Edwardsville.

DEWEY J., LW, (1981-1990), The Later Works of John Dewey, 1925-1953, ed. by J. A. Boydston, Southern Illinois University Press, Carbondale and Edwardsville.

DEWEY J., UP (2012), Unmodern Philosophy and Modern Philosophy, Phillip Deen ed., with a foreword by Larry A. Hickman, Carbondale, Southern Illinois University Press.

GOULD S. J. \& E. S. VRBA, (1982), “Exaptation-a Missing Term in the Science of Form,” Paleobiology, $8,1,4-15$.

JoHnson M., (2007), The Meaning of the Body: Aesthetics of Human Understanding, Chicago, Ill., The University of Chicago Press.

KIRK G. S. \& J. E. RAVEN, (1957/1975), The Presocratic Philosophers, Cambridge, Cambridge University Press. KR in the text.

LAKOFF G. \& M. JOHNSON, (1999), Philosophy in the Flesh, New York, Basic Books.

MOORE G., (2002), Nietzsche, Biology and Metaphor, Cambridge, Cambridge University Press. 
MOST G. W. \& T. FRIES, (2014), “The Sources of Nietzsche's Lectures on Rhetoric," Nietzsche as a Scholar of Antiquity, A. Jensen \& H. Heit (ed.), Bloomsbury, 53-74.

NIETZSCHE F., (1872/1999). The Birth of Tragedy: And Other Writings, Ronald Speirs (trans.), Cambridge, Cambridge University Press.

NIETZSCHE F., (1872-1873/1989), Friedrich Nietzsche on Rhetoric and Language, ed. by S. L. Gilman, C. Blair \& D. J. Parent, Oxford, Oxford University Press.

NIETZSCHE F., (1873/1998), Philosophy in the Tragic Age of the Greeks, Washington, D. C., Regnery Publishing, Inc.

NIETZSCHE F., (1873/1999), "On Truth and Lying in a Non-Moral Sense," in The Birth of Tragedy, Cambridge, Cambridge University.

NIETZsChe F., (1878/1986), Human, All Too Human, Cambridge, Cambridge University Press.

NIETZSCHE F., (1882/1974), The Gay Science, W. Kaufmann (trans.), New York, Vintage Books.

NIETZSCHE F., (1887/1967), On The Genealogy of Morals, W. Kaufmann and R. J. Hollingdale (trans.), New York, Vintage Books.

NIETZSCHE F., (1886/1966), Beyond Good and Evil, W. Kaufmann (trans.), New York,Vintage Books. NIETZsChe F., (1889/2005), Nietzsche: The Anti-Christ, Ecce Homo, Twilight of the Idols, Cambridge, Cambridge University Press.

NIETZSCHE F., (1901/1967), Will To Power, W. Kaufmann (trans.), New York, Vintage Books.

NIETZSCHE F., (1979), "The Philosopher: Reflections on the Struggle Between Art and Knowledge," in Breazeale D. ed., Philosophy and Truth: Selections from Nietzsche's Notebooks of the Early 1870's, Atlantic Highlands, Humanities Press.

PORTER J. I., (1994), “Nietzsche's Rhetoric: Theory and Strategy,” Philosophy and Rhetoric, 27, 3, 218-44.

RABINOW P., (2011), “Dewey and Foucault: What's the Problem?,” Foucault Studies, 11/2011, 11-9.

RYAN F. X., (2011), Seeing Together: Mind, Matter, and the Experimental Outlook of John Dewey and Arthur F. Bentley, Great Barrington, MA, American Institute for Economic Research.

SCHADEWALDT W., (1979), "The Concepts of Nature and Technique According to the Greeks," in Research in Philosophy and Technology, vol. 2, P. T. Durbin (ed.), Greenwich, Connecticut, JAI Press, 159-71.

SCHRIFT A. D., (1990), Nietzsche and the Question of Interpretation, New York, Routledge.

SCHRIFT A. D., (1996), “Nietzsche’s French Legacy,” in B. Magnus \& K. M. Higgins (eds.), The Cambridge Companion to Nietzsche, Cambridge, Cambridge University Press.

STACK G. J., (1981), “Nietzsche and the Correspondence Theory of Truth,” Dialogos 38, 93-117.

wilcox J. T., (1986), “Nietzsche Scholarship and 'The Correspondence Theory of Truth': The Danto Case," Nietzsche-Studien 15, 337-57.

\section{NOTES}

1. Nowhere have emphasis been added to any citation. 
2. Stephen Toulmin, one of the foremost rhetoricians of the twentieth century, writes the Introduction to the Carbondale edition of The Quest for Certainty. See also Crick 2010.

3. There are important disanalogies. Dewey would reject Nietzsche's nominalism, vitalistic will to power, Übermensch, and more. However, their shared poetic perspectival empirical naturalism is the topic of this paper.

4. For connections between Foucault's genetic (i.e., historical) method and Dewey's, see Rabinow 2011. Foucault freely acknowledges Nietzsche influence.

5. "Exaptation" is the process by which structures originally selected or adapted to perform one function evolve to perform entirely different functions. See Gould and Vrba 1982. We may extend the same idea to the evolution of cultural meanings and values. The so-called "genetic fallacy" poses no problems for Nietzsche and Dewey.

6. Nietzsche and Dewey break the stranglehold the following Parmenidian maxim has had on Western thought, "the same thing exists for thinking and for being" (See KR: Fr. 352).

7. Being merely lexicographer's entries regarding common usage, dictionary definitions are rarely good enough for philosophical purposes. We start with such definitions of various tropes to provide the reader with a sense of standard usage.

8. I acknowledge the ongoing debate over the value of Nietzsche's largely philological Rhetoric. Most and Fries have shown that the Rhetoric is largely a "collage" of work by other rhetoricians. Since I am using the Rhetoric along with the OED largely to establish the culturally entrenched usage of various tropes, this indebtedness to tradition works well for me. However, they also remark on the importance of Nietzsche accepting Gustav Gerber's assertion that all words are originally tropes. They then note that Nietzsche rejected Gerber's methodological distinction between the aesthetics of language and the theory of language while dramatically modifying his tropological interpretation by insisting, "language is rhetoric" (Most, Fries 2014: 57-58). Oddly, they repeatedly characterize the identification of language with rhetoric as "totalitarian." I say oddly, since it seems to me to render totalization impossible: "The possibility of rhetorical deconstruction, which, as a result of this totalitarian sentence ["language is rhetoric"], seems to offer itself up as a critique of any discourse in any field, effacing the borders between distinct fields of knowledge, is thereby related to its own preconditions - relegated to its own compensatory, active "poeticization... Nietzsche's productive insight... puts everything in relation to everything else but at the same time revokes the foundation of the individual disciplines, especially philosophy... In this sense, the collation of classical philological and language-philosophic rhetoric, which we have understood as the deciding factor for Nietzsche's lectures on rhetoric, leads to a dead end" (Most \& Fries 2014: 66). Strangely, one of the most obvious things about the "totalitarian sentence" is that such anti-foundationalism leads directly to French post-structuralism, which Most and Fries deride. It also leads to a rhetorical dead end that helps prod Nietzsche into philosophy beginning with the philosophy of language found in "On Truth and Lying." James I. Porter takes a different tack; he wonders: "Could Nietzsche's affirmation of the rhetorical essence of language itself be part of a larger rhetorical strategy?" (Porter 1994: 221). He answers: “yes!": "Rhetoric scandalizes thought and language because it brings them back to our senses, confronts us with all their historical and contextual contingence, and renders thought both materially present... and, we might say, materially intelligible intelligible insofar as it has a material history, which is emphatically not the same as the abstract and ideal intelligibility that thoughts expression would present by itself" (Porter 1994: 222). This genetic, material, and contingent intelligibility disturbs Most and Fries. Porter concludes: "One of Nietzsche's aims in his essay 'On Truth and Lying' is to replenish the sensory dimensions of concepts and words" (Porter 1994: 224).

9. It is unclear if Lakoff and Johnson would countenance Nietzsche's first stage. However, it seems to me to express Dewey's psycho-physical level of functioning quite well. Dewey states: "Organic and psycho-physical activities with their qualities are conditions which have to come 
into existence before mind... They supply mind with its footing and connection in nature; they provide meanings with their existential stuff" (LW 1: 220). There is no reason not to extend the source domain for abstract mental functioning down to its "existential stuff."

10. Johnson 2007 emphasizes the primacy of the aesthetic encounter. To map from a sensorimotor domain to an abstract domain is an instance of artistic creativity arising from an aesthetic encounter.

11. The second half of Philosophy in the Tragic Age of the Greeks would have included "On Truth and Lying" (see Cox 1999: 185, fn. 39).

12. Here, we will not consider Nietzsche's eternal return as a metaphysical principle. Many scholars contend we should read "the greatest weight" exclusively as an ethical challenge.

13. For more on Nietzsche's rejection of self-identity, see de Man 1975.

14. Such observations also confound linguistic neo-pragmatists and others devoted to propositional attitudes and the like. Language is simply an important phase in the creative development of human experience.

15. Dewey rejects the very idea of pure reason: "Reasonableness or rationality has, however, been hypostatized. One of the oldest and most enduring traditions in logical theory has converted rationality into a faculty which, when it is actualized in perception of first truths, was called reason and later, Intellectus Purus. The idea of reason as the power which intuitively apprehends a priori ultimate first principles persists in logical philosophy." (LW 12: 18). The hypostatized and reified noun "rationality" is perhaps the most influential version of "the philosophic fallacy."

16. Arguing against both Nietzsche and Arthur Danto (1965), Wilcox contends that if an assumption is false a statement has no reference; hence, it is neither true nor false. He does agree with Danto that Nietzsche rejects the possibility of a metaphysical concept of "Truth" as correspondence with noumenal reality behind appearances (Wilcox 1986: 343).

17. Dewey indicates, "nerve-elements interact with external physical changes in bringing about the occurrence of certain perceived qualities" (LW 2: 44). Dewey is comfortable with Nietzsche's first stage of metaphorical translation.

18. Dewey is thinking in terms of the classical Greek "aesthetikos" meaning sensory perception, sensitivity, sentience, and feel. He rejects Kant's aesthetics of the beautiful.

19. Dewey asserts: "A scientific description is logically adequate in the degree in which it consists of a group of coexistent traits which so identify an object that anything having these traits, and only those having them, is of such and such a kind" (LW 12: 239).

20. It is amusing to imagine contexts and purposes for which this figure works.

21. Of course, any simile may succeed poetically, post-structurally, or what have you. However, in a world where over $99 \%$ of all species (eidos, essences) that have ever existed are now extinct practical consequences matter.

22. Mathematically " $\mathrm{pH}$ " is the negative logarithm of hydrogen ion concentration.

23. Dewey states: "The word 'is' in such instances as these has existential force not that of the timeless (because strictly logical) copula" (LW 12: 289). Again, all is clear as long as we attend to the existence versus essence distinction.

24. Dewey notes these are sometimes 'called 'Propositions of Sense Perception,' although that can be confusing" (LW 12: 291).

25. It is also a constant temptation linguistic pragmatists and poststructuralist alike.

26. Dewey's two-part paper, "The Evolutionary Method As Applied to Morality" has many remarkable similarities to Nietzsche's Genealogy of Morals including the defiance of the "is" versus "ought" and "fact" versus "value" dualisms.

27. Later, Dewey would use the word "situation" to designate what he here calls "fact." A dead body is Dewey's example of a "fact" requiring resolution. The work of the detective is to form a 
warranted assertion (a judgment) from selected evidence used to carry out existential inferences and formal implications to solve the case (i.e., resolve the doubtful situation).

28. See Moore 2002. For Dewey's own critique of "the will to power," see Dewey (MW 14: 97-100). The status of "the will to power" remains debatable among Nietzschean scholars.

29. See also (UP: 219, 321, 329, 331, and 334).

30. Dewey thinks, "it may be said that a question about ultimate origin or ultimate causation is either a meaningless question, or else the words are used in a relative sense to designate the point in the past at which a particular inquiry breaks off" (MW 8: 5).

31. Linguistic propositions are also simply subfunctions of the function of inquiry. Indeed, Dewey insists, "all logical forms (with their characteristic properties) arise within the operation of inquiry and are concerned with control of inquiry so that it may yield warranted assertions" (LW 12: 11).

\section{ABSTRACTS}

My paper focuses on the following famous passage from Friedrich Nietzsche's "Truth and Lying in a Non-Moral Sense": "What, then, is truth? A mobile army of metaphors, metonyms, and anthropomorphisms" (OTL 1). I will show that John Dewey entirely agrees with this statement. Dewey and Nietzsche has a rich and novel understanding of metaphor, metonymy, simile, and such that they use to comprehend the creation of linguistic meanings, the identity of things, the creation of objects (essences, eidos, etc.), cause and effect, free will, and necessity as serving anthropomorphic purposes. My conclusion presents Dewey as a gay scientist joining Nietzsche in making creative use of the genetic method. The result of is a surprisingly poetic and rhetorical interpretation of Dewey that should not astonish anyone who reads him carefully. We arrive at this radical reading of Deweyan pragmatism by a metaphorical transfer from Nietzsche as the more familiar source domain to Dewey as the target domain. All along the way, things will fall into place if we carefully distinguish our anoetic experience of existence from the cognitive linguistic meanings, identities, and essences we create from our experience of existence.

\section{AUTHOR}

\section{JIM GARRISON}

Virginia Tech, Blacksburg

Wesley[at]vt.edu 